(C) The Author(s) 2020. Published by Cambridge University Press for the British Institute of International and Comparative Law. This is an Open Access article, distributed under the terms of the Creative Commons Attribution-NonCommercial-NoDerivatives licence (http://creativecommons.org/licenses/by-nc-nd/4.0/), which permits non-commercial re-use, distribution, and reproduction in any medium, provided the original work is unaltered and is properly cited. The written permission of Cambridge University Press must be obtained for commercial re-use or in order to create a derivative work.

\title{
THE HUMAN RIGHTS COMMITTEE, ENVIRONMENTAL PROTECTION AND THE RIGHT TO LIFE
}

\author{
GineVRa Le Moli*
}

\begin{abstract}
In its August 2019 decision in Portillo Cáceres v Paraguay, the Human Rights Committee recognised, for the first time, the existence of a connection between environmental protection and the right to life with dignity. This is not only a landmark decision for the Committee but also represents the consolidation of a body of case law and practice from the three regional human rights courts and other UN human rights bodies which has developed over the last quarter of a century. It also shows the potential of two important and widely debated paragraphs in the newly adopted General Comment No. 36 on the Right to Life, which describe environmental degradation as both an enabler of threats and a direct threat to the right to life. Such potential has been confirmed in another landmark decision of the HRC-Teitiota $v$ New Zealand, relating to climate change as threat to life. This article draws on Portillo Cáceres $v$ Paraguay and Teitiota $v$ New Zealand to analyse this wider field of practice in order to clarify the connection between the right to life and environmental protection, as recognised by the Committee, and considers its potential impact on future litigation.
\end{abstract}

Keywords: human rights, public international law, Portillo Cáceres v Paraguay, Teitiota $v$ New Zealand, General Comment No 36 on the Right to Life, right to life, dignity, Human Rights Committee, environmental degradation, climate change, non-refoulement.

\section{INTRODUCTION}

On 9 August 2019 the Human Rights Committee (HRC) issued a landmark decision in the case Portillo Cáceres v Paraguay. ${ }^{1}$ For the first time in its jurisprudence, ${ }^{2}$ it explicitly recognised that a State's failure to take action

* Assistant Professor of Public International Law at the Institute of Public Law and the Grotius Centre for International Legal Studies at Leiden University, g.le.moli@law.leidenuniv.nl.

1 Portillo Cáceres v Paraguay (HRC, 9 August 2019, Comm No. 2751/2016), CCPR/C/126/D/ 2751/2016, para 2.3

2 The HRC received over the years a significant number of communications that touched upon the link between environmental degradation and human rights, most notably in connection with nuclear waste, eg, see E.H.P. v Canada (HRC, 27 October 1982, Comm No. 67/1980). On the cultural rights of indigenous peoples, eg Kitok v Sweden (HRC, 27 July 1988, Comm No. 197/ 1985); Bernard Ominayak and the Lubicon Lake Band v Canada, (HRC, 26 March 1990, Comm 
against environmental harm can violate its obligations to protect the rights to life and to private and family life under Articles 6 and 17 of the International Covenant on Civil and Political Rights (ICCPR). ${ }^{3}$ This is not only a landmark decision for the HRC; it is also the first decision from a United Nations (UN) Treaty Body which clearly addresses and consolidates a link which, until now, had essentially been developed in the jurisprudence of regional human rights courts. ${ }^{4}$ The decision is also noteworthy because it relies on the recently adopted General Comment No. 36 on the right to life (GC No. 36), ${ }^{5}$ which includes two specific paragraphs on the relationship between human rights and the environment. ${ }^{6}$ Importantly, on 24 October 2019, the HRC rendered another landmark decision in the case Teitiota $v$ New Zealand, which confirmed the potential of GC No. 36 to address matters relating to climate change, displacement and the right to life. ${ }^{7}$

This article uses Portillo Cáceres v Paraguay and Teitiota $v$ New Zealand as the starting points for an analysis of the current state of the jurisprudence on environmental protection and the right to life, at both the international and regional levels. The first section examines both decisions and their significance for the practice of the HRC. As noted earlier, one relevant aspect of these decisions is their reliance on GC No. 36. The second and third sections of the article discuss at length the relevant paragraphs of this general comment, shedding light on the different views expounded within the HRC during the drafting process. This discussion is intended to clarify the relevance of these paragraphs for the decisions in Portillo Cáceres and in Teitiota and, more

No. 167/1984); Poma Poma v Peru (HRC, 27 March 2009, Comm No. 1457/2006). But, in addressing these cases, it did not elaborate on such link.

3 International Covenant on Civil and Political Rights (16 December 1966) United Nations, Treaty Series, vol 999, at 171.

4 In the case law of the ECtHR, see the leading case in the European context Lopez Ostra $v$ Spain, ECtHR App No. 16798/90, Judgment of 9 December 1994, while a retrospective of the case law appears in the most recent Cordella and Others $v$ Italy, ECtHR App No. 54414/13 and 54264/15, Judgment of 24 January 2019; for the case law of the IACtHR, as a leading decision, see Mayagna (Sumo) Awas Tingni Community v Nicaragua, ICtHR Series C No 79, Judgment of 31 August 2001, while a retrospective of the case law appears in its most recent position in the Advisory Opinion requested by the Republic of Colombia: Environment and Human Rights (State obligations in relation to the environment within the framework of the protection and guarantee of the rights to life and to personal integrity-interpretation and scope of Articles 4.1 and 5.1 in relation with Articles 1.1 and 2 of the American Convention on Human Rights), IACtHR, OC23/17, Opinion of 15 November 2017, Serie A No. 23 [Advisory Opinion on Human Rights and the Environment]; for the African region, see ACommHPR, see Social and Economic Rights Action Center (SERAC) and others v Nigeria (ACommHPR, 27 May 2002 (Ogoni), App No. 155/96) para 3 ['Ogoni Case'] and ACtHPR, African Commission on Human and Peoples' Rights v Kenya, Judgment (26 May 2017), African Court App No. 006/2012 [Ogiek Case]. See further, for an overview, PM Dupuy and JE Viñuales, International Environmental Law (2nd edn, Cambridge University Press 2018) 365-74.

5 General Comment on Right to Life No. 36 (2018), CCPR/C/GC/36 ['GC No. 36'].

6 ibid, see paras 26 and 62.

7 Teitiota v New Zealand (HRC, 24 October 2019, Comm No. 2728/2016), CCPR/C/127/D/ $2728 / 2016$ in particular see paras 9.4-9.5. 
generally, for future cases before the $\mathrm{HRC}^{8}$ and other international forums. The 'jurisprudence' of the HRC, as the International Court of Justice (ICJ) has referred to this body of decisions, ${ }^{9}$ has been influential in several forums, including regional human rights courts ${ }^{10}$ and the ICJ itself. ${ }^{11}$ The fourth section places the discussion within the wider context of the development, mainly since the early 1990s, of a substantial body of decisions providing some degree of protection to the environment through the reinterpretation of 'general' human rights, ie human rights which make no explicit reference to the environment, such as the right to life. ${ }^{12}$ The final section conceptualises this jurisprudential evolution.

As has been argued in the literature, ${ }^{13}$ environmental protection and general human rights have been linked in two main ways: one which requires a certain level of environmental protection as a necessary condition for the protection of the integrity of human beings and another which protects the cultural link between individuals, groups and their environment. The jurisprudence of the HRC had focused mainly on the cultural bridge, on the basis of Article 27 of the ICCPR, ${ }^{14}$ with cases relating to integrity faring less well. ${ }^{15}$ The decisions in Portillo Cáceres and Teitiota however bring balance to the HRC's jurisprudence and, due to the global scope of the ICCPR, set an important precedent for the understanding of environmental protection as a component of the right to life.

8 See the (currently pending) Petition of Torres Strait Islanders to the United Nations Human Rights Committee Alleging Violations Stemming from Australia's Inaction on Climate Change (Torres Straits Islanders v Australia), (HRC, 12 May 2019), press release, ClientEarth, 'Climate Threatened Torres Strait Islanders Bring Human Rights Claim against Australia' (ClientEarth, 12 May 2019) <https://www.clientearth.org/press/climate-threatened-torres-strait-islanders-bringhuman-rights-claim-against-australia/>.

9 See Ahmadou Sadio Diallo (Republic of Guinea v Democratic Republic of the Congo), ICJ, Merits, Judgment, ICJ Reps 2010, at 639, para 66.

10 See, for instance, Tanganyika Law Society and Legal and Human Rights Centre v United Republic of Tanzania, and Reverend Christopher $R$ Mtikila $v$ United Republic of Tanzania, ACtHPR App No. 009/2011 and 011/2011, Judgment of 14 June 2013, para 105.4; see also references in the IACtHR Advisory Opinion on Human Rights and the Environment (n 4) para 79.

11 Ahmadou Sadio Diallo (n 9) paras 66 and 77.

12 For overviews see Dupuy and Viñuales (n 4) 365-74; Report of the Special Rapporteur on the issue of human rights obligations relating to the enjoyment of a safe, clean, healthy and sustainable environment, John H. Knox, Implementation Report, December 2015, A/HRC/31/53; Framework Principles on Human Rights and the Environment, 24 January 2018, A/HRC/37/59.

13 Dupuy and Viñuales (n 4) 368.

14 See Kitok $v$ Sweden (n 2), paras 9.2-9.3 [concluding that no violation of art 27 of the ICCPR occurred, see paras 9.5-9.8]; Bernard Ominayak and the Lubicon Lake Band v Canada (n 2) paras 32.2-33 [concluding that a violation of art 27 of the ICCPR occurred] and the discussion in D McGoldrick, 'Canadian Indians, Cultural Rights and the Human Rights Committee' (1991) 40 ICLQ 658-69; Poma Poma v Peru (n 2) paras 7.1-8 [concluding that a violation of art 27 occurred].

${ }_{15}$ Being dismissed as inadmissible or on the merits, see E.H.P. v Canada (n 2) paras 8-9; Bordes et Temeharo v France (HRC, 22 July 1996, HRC Comm No. 645/1995) paras 5.5-6; Brun v France (HRC, 18 October 2006, Comm No. 1453/2006) para 6.3. 
The case Portillo Cáceres $v$ Paraguay was initiated by members of families farming in the Department of Canindeyú, District of Curuguaty, who complained that the application of pesticides to soy farms in the area had resulted in the death of one person and the poisoning of many others. Curuguaty is an area in which there has been a great expansion of agribusiness and extensive and mechanised monoculture of genetically modified soybeans. The massive use of agro-toxics in this area had a serious impact on the living conditions, domestic economies and health of the claimants. ${ }^{16}$ In particular, the contamination of water and aquifer resources not only rendered impossible the use of two streams (the Yerutí and Kuairû) for fishing, but also caused the loss of fruit trees, the death of various breeding animals, and the deterioration of crops. Above all, the high level of pollution ultimately led to the death of Mr Portillo Cáceres, a 26-year-old farmer, in 2011, and to the poisoning of the complainants, who filed an amparo - a legal action for the protection of constitutional rights. On 15 April 2011, the court of the District of Curuguaty, concluded that, by failing to discharge its duties, the Ministry of the Environment and the National Plant and Seed Quality and Health Service had enabled serious physical harm to be caused to the complainants. ${ }^{17}$ However, despite this decision, soybean producers continued to use large quantities of agrochemicals without environmental permits or environmental protection measures. ${ }^{18}$

In this context, the complainants contended before the HRC that, eight years on, the State was still in violation of its duty to protect, by not acting diligently and by continuing to allow the extensive spraying of agro-toxins in farms adjacent to their homes without respect for current regulations. ${ }^{19}$ They claimed that these acts had been committed by public officials in the exercise of their official functions and that the failure to regulate agro-toxics constituted a violation of Articles 6 (right to life), 7 (prohibition of torture and cruel/inhuman/degrading treatment) and 17 (right to private and family life) of the ICCPR. ${ }^{20}$ Moreover, the complainants claimed there was also a violation of the right to an effective judicial remedy (Article 2(3)(a)), since the environmental contamination which had led to the death of Mr Portillo Cáceres had not been investigated effectively, appropriately, impartially and diligently, and it remained unpunished. ${ }^{21}$

After finding that there were no obstacles to the admissibility of the complaint, the Committee considered each of the arguments advanced by the complainants on their merits. Regarding the alleged violation of the right to life, the Committee noted that the well-documented massive aerial spraying with agro-toxic substances constituted a threat to the lives of the

16 Portillo Cáceres v Paraguay (n 1) para 2.5.

18 ibid, para 2.23. 19 ibid, para 3.1.

20 ibid, para 3.4. $\begin{array}{r}17 \text { ibid, para } 2.20-2.22 \text { ibid, para 3.8. } \\ \end{array}$ 
complainants which was reasonably foreseeable by Paraguay. ${ }^{22}$ Given the serious poisoning suffered by the complainants, already recognised by the amparo ruling of $2011,{ }^{23}$ and the death of $\mathrm{Mr}$ Portillo Cáceres, the Committee concluded that there had been a violation of the right to life (Article 6). Significantly, this decision relied for the first time on the newly adopted GC No. 36 on the right to life. The Committee also concluded that Paraguay had not put in place adequate controls over illegal polluting activities and, therefore, it had violated Article 17. ${ }^{24}$ Finally, given that over eight years had passed since the events in question, that investigations had not progressed and had not led to any form of redress for the harm suffered, the Committee concluded that Paraguay had not acted in accordance with Article 2(3)(a) of the ICCPR, which requires the provision of an effective remedy. In this regard, the HRC emphasised that a State party has to: '(a) undertake an effective, thorough investigation into the events in question; (b) impose criminal and administrative penalties on all the parties responsible for the events in the present case; (c) make full reparation, including adequate compensation, to the authors for the harm they have suffered.' ${ }^{25}$ It is also under the obligation to take measures to prevent similar offences being committed in the future. ${ }^{26}$ Paraguay had failed on all these counts.

Nearly two months later, on 24 October 2019, the Committee confirmed its interpretation of Article 6 in a second landmark decision in the case Teitiota $v$ New Zealand. The complaint was brought by Ioane Teitiota, a national of the Republic of Kiribati, against New Zealand. Teitiota had applied for asylum in New Zealand, arguing that the effects of climate change and sea level rise had forced him to migrate from the island of Tarawa, in the Republic of Kiribati, which 'had become an untenable and violent environment for him and his family', ${ }^{27}$ to New Zealand. The Immigration and Protection Tribunal issued a negative decision concerning his claim for asylum. ${ }^{28}$ The Court of Appeal and the Supreme Court both denied subsequent appeals due to the absence of substantial grounds for believing that the claimant or any of his family members would be in danger of a violation of their rights under Article 6 of the Covenant. ${ }^{29}$ There was no evidence establishing that his situation in the Republic of Kiribati would be so precarious as to threaten his or his family's life. However, neither the Tribunal nor the Supreme Court excluded the possibility that environmental degradation could 'create pathways into the Refugee Convention or protected person jurisdiction'. ${ }^{30}$

In September 2015, Mr Teitiota filed a complaint before the HRC, claiming that, by sending him to Kiribati, New Zealand had subjected him to a risk to his life in violation of Article 6, and that New Zealand's authorities had not properly assessed the risk inherent in his removal. He argued that 'sea level rise in 
Kiribati has resulted in: (a) the scarcity of habitable space, which has in turn caused violent land disputes that endanger the author's life; and (b) environmental degradation, including saltwater contamination of the freshwater supply'. ${ }^{31}$ The Committee dismissed the communication on the merits explaining that it could only reverse a State's determination if it had been clearly arbitrary or amounted to a manifest error or a denial of justice. The HRC thus upheld New Zealand's determination that Mr Teitiota had not sufficiently substantiated that he faced a real risk to his life and concluded that there was no violation of Article 6(1) of the Covenant. ${ }^{32}$ Yet, as discussed later in this article, in reaching this conclusion, the Committee made important remarks on the connection between the right to life, climate change and the principle of non-refoulement.

\section{THE ENVIRONMENT OF A LIFE WITH DIGNITY}

As already mentioned, in Portillo Cáceres the HRC relied on GC No. 36 for the first time. The GC had three years of 'gestation', from 2015 to 2018 when the HRC adopted it unanimously. The first draft was meticulously crafted by Special Rapporteurs Yuval Shany and Nigel Rodley in $2015^{33}$ and, when adopted in November 2018, it replaced two earlier general comments No. 6 (16th session) and 14 (23rd session), adopted by the Committee in 1982 and 1984 respectively. ${ }^{34}$ GC No. 36 includes two paragraphs specifically devoted to the relationship between human rights and the environment, namely paragraphs 26 and 62. Paragraph 26, under the section III of the GC No. 36 on the 'Duty to Protect', reads as follows:

The duty to protect life also implies that States parties should take appropriate measures to address the general conditions in society that may give rise to direct threats to life or prevent individuals from enjoying their right to life with dignity. These general conditions may include [...] degradation of the environment $[\ldots]$

Under section IV of the GC, concerning the 'Relationship of article 6 with other articles of the Covenant and other legal regimes', paragraph 62 further clarifies that:

Environmental degradation, climate change and unsustainable development constitute some of the most pressing and serious threats to the ability of present and future generations to enjoy the right to life. Obligations of States parties under international environmental law should thus inform the contents of article 6 of the Covenant, and the obligation of States parties to respect and ensure the right to life should also inform their relevant obligations under international environmental

31 ibid, para 3.

32 ibid, para 10.

33 See Draft GC 36, HRC, Session 115th (2 September 2015) CCPR/C/GC/R.36/Rev.2.

34 GC No. 36 (n 5) para 1. 
law. Implementation of the obligation to respect and ensure the right to life, and in particular life with dignity, depends, inter alia, on measures taken by States parties to preserve the environment and protect it against harm, pollution and climate change caused by public and private actors. [...]

To understand the scope and implications of these paragraphs it is necessary to examine the preparatory works of GC No. 36, including discussions concerning the 'duty to protect'. This helps explain the relevance of paragraphs 26 and 62 both for the decision in Portillo Cáceres and, more generally, for future decisions.

It was during the 118th session of the HRC, when the draft had already been debated for a year, that the topic of environmental impact and degradation was first brought to the attention of the Special Rapporteurs. ${ }^{35}$ At the beginning of the session, Special Rapporteur Shany had already clarified that paragraph 21 (now 18) represented an umbrella statement contextualising the meaning of the obligation to protect the right to life, and it was thus aptly placed at the opening of the section III of the Draft GC No. 36 on 'the Duty to Protect Life'. This paragraph set out the basis of the duty to protect. In Shany's words, the concept of 'protection by law' constituted the foundation of two 'ideas' both of which are enshrined in Article 6, namely 'the duty to adopt a protective legal framework for the right to life and the duty to provide protection in accordance with that legal framework' ${ }^{36}$ He further noted that the latter duty is also supported by the duty to ensure the right to life, Article 2 of the ICCPR, ${ }^{37}$ and that both are 'cumulative, though independent, obligations' that States must implement. ${ }^{38}$

The specific object of discussion at the start of the 118th session was the text of paragraph 25 (now 22), which referred to the States' obligation to ensure that 'all activities taking place in whole or in part within their territory and in other areas subject to their jurisdiction, but having a [direct], significant and foreseeable impact on the right to life of individuals outside their territory [...]' were consistent with Article 6 of the Convention. Committee member Mauro Politi asked whether it was necessary to refer to a 'direct, significant and foreseeable impact', when a 'potential' impact on the right to life could also result from activities which caused transboundary pollution. ${ }^{39} \mathrm{Mr}$ Politi, supported by Committee member De Frouville ${ }^{40}$ drew attention to Principle 21 of the Stockholm Declaration on the Human Environment. ${ }^{41}$ This, he

\footnotetext{
35 Discussion of the GC No. 36, HRC, 3321st meeting, 118th Session (25 October 2016) <http:// webtv.un.org/meetings-events/human-rights-treaty-bodies/human-rights-committee/120thsession/watch/general-comment-on-article-6-3321 st-meeting-118th-session-of-human-rightscommittee $/ 5186926832001 /$ ?term $=\&$ lan $=$ english $>$ [Written transcripts not available].

36 ibid, remark by Special Rapporteur Mr Yuval Shany on para 21, 0.18.25 min.

37 ibid, 0.18.46 min. $\quad 38$ ibid, 0.21.52 min. $\quad 39$ ibid, Mr Mauro Politi, 1.13.00 min.

40 ibid, Mr Olivier de Frouville, 1.23.16 min.

41 ibid, Mr Mauro Politi, 1.25.12 min. See Declaration of the United Nations Conference on the Human Environment, 15 December 1972, Stockholm from 5 to 16 June 1972, A/RES/2994 ['Stockholm Declaration'].
} 
argued, represented customary international law and meant that 'States have [...] the responsibility to ensure that activities within their jurisdiction or control do not cause damage to the environment of other States or of areas beyond the limits of national jurisdiction' ${ }^{42}$ He explained that, according to the Stockholm Declaration, States have a duty to ensure that no damage is caused to the environment and, 'even more, a duty to ensure, to prevent and avoid that acts cause deprivation of life in territories outside the limits of their jurisdiction. [...] This provision constitutes a well settled principle of the law of the environment.' 43 In response, Special Rapporteur Shany drew attention to the term 'to ensure' and its direct connection to the duty of due diligence. ${ }^{44}$ The debates were thus reoriented towards environmental considerations.

What became paragraph 26 of the GC No. 36 was discussed the following day. ${ }^{45}$ In his opening remarks, Special Rapporteur Shany clarified that paragraph 29 (now 26) concerned long-term measures designed to protect the right to life. He observed that whilst paragraph 29 (now 26) reflected paragraph 5 of the 1982 GC on the right to life, ${ }^{46}$ the new GC No. 36 took it a step further by providing examples from other areas, such as 'traffic or industrial accidents'. In addition, he also noted that the principal and most difficult issues concerning this paragraph related to the relationship between economic, social, and cultural rights. Since the focus of the paragraph was on the 'conditions that may give rise to threat to right to life', this justified the 'bundle' of various illustrations of possible sources of threat. ${ }^{47}$ Indeed, GC No. 36 had to refer not only to negative and to ordinary positive obligations, but also to a third category of positive obligations of 'special character', since it did not 'deal with the immediate violation' but 'with the conditions of the causes of the violation', going 'one step back'. ${ }^{48} \mathrm{He}$ argued that this merely built on GC No. 6, which 'showed the way', since 'to effectively protect the right to life, it is not possible to intervene at the very last minute and states need to deal with the causes of the violation'. ${ }^{49}$ Not dealing with the causes would be like 'closing the stable door after the horse has bolted' ${ }^{50} \mathrm{He}$ also added that the reference to threats to the enjoyment of a 'dignified existence' encompassed both the right to physical existence and its substantive content. However, following a comment from

42 ibid, $1.25 .22 \mathrm{~min}$.

43 ibid, $1.25 .46 \mathrm{~min}$.

44 ibid, Special Rapporteur Mr Yuval Shany, 1.26.50 min.

45 Discussion of the GC No. 36 (Cont'd), HRC, 3323rd meeting, 118th Session (26 October $2016)<$ http://webtv.un.org/meetings-events/human-rights-treaty-bodies/human-rights-committee/ 120th-session/watch/general-comment-on-article-6-contd-3323rd-meeting-118th-session-ofhuman-rights-committee/5186926875001/?term=\&lan=english $>$.

46 CCPR General Comment No. 6: Art 6 (Right to Life), 30 April 1982 ['GC No. 6’].

47 Discussion of the GC No. 36 (Cont'd), HRC, 3323rd meeting, 118th Session (n 45), Special Rapporteur Mr Yuval Shany, 1.22.00 min. $\quad 48$ ibid, 1.23.41 min. 49 ibid, $1.24 .10 \mathrm{~min}$

$50 \mathrm{ibid}, 1.25 .00 \mathrm{~min}$. 
Committee member Yuji Iwasawa, ${ }^{51}$ it was agreed that 'right with dignity' was a better formulation.

The following day a new text was circulated, ${ }^{52}$ which included an express reference to 'pollution of the environment' in the list of possible conditions giving rise to direct threats to life. ${ }^{53}$ This was not returned to until the $123 \mathrm{rd}$ session in July 2018. ${ }^{54}$ Special Rapporteur Shany reminded members that, in the first round of drafting, paragraph 30 (now 26) had been a 'difficult paragraph'. 55 Recalling that it dealt with the relationship between the right to life and the general conditions of society that may give rise to direct threats to the right to life or prevent from enjoying such a right with dignity, he observed that

the idea is that the duty to protect the right to life or the duty to ensure the right to life also require states to address these more structural long-term challenges. This is how we try to deal with it. The language used is sometimes 'should', because we are realizing that sometimes we walk on the borderline of obligations and best practices but sometimes we use a stronger language ${ }^{56}$

He then set out a series of considerations, doubts and suggestions that had been received from States, NGOs and private individuals.

States such Australia, the United States of America and Denmark, had expressed concern as to whether the HRC was setting out new legal obligations. The Special Rapporteur clarified that the General Comment would set out the expectations of the HRC regarding how States would be expected to implement their existing obligations, rather than creating new.

Moreover, Canada had raised a specific concern regarding the notion of 'life with dignity'. On this issue, however, Special Rapporteur Shany held his ground:

I think is one of the most important aspects of this General Comment meaning that we understand the right to life as entailing a right to life with dignity. For the reason that we have already discussed, I don't propose that we go back on this very important principle. ${ }^{57}$

51 The expression 'dignified existence' can be indeed traced mostly in the case law of the IACtHR and of the ACommHPR, see, for instance, Advisory Opinion on Juridical Condition and Rights of the Undocumented Migrants (IACtHR, 17 September 2003, OC-18/03) para 158; see also General Comment No. 3 on the African Charter on Human and Peoples' Rights: The Right to Life (Article 4), Adopted during the 57th Ordinary Session of the African Commission on Human and Peoples' Rights held from 4 to 18 November 2015, Introduction, para 3.

52 Draft General Comment No. 36 for discussion on Wednesday 2 November 2016, trackchanges version of paragraphs 26 to 31 compared to Rev. 2 (basis document), para 26. The document is on file with the author.

53 Subsequently, see Draft GC No. 36 circulated on the HRC 3353rd Meeting, 119th Session (15 March 2017) para 27 (now 26); see Draft GC No. 36 circulated on the HRC 3437th Meeting, 121st Session (1 November 2017) para 30.

${ }^{54}$ GC No. 36, (Part 3), HRC, 3513th Meeting, 123rd Session (18 July 2018) <http://webtv.un. org/meetings-events/watch/part-3-general-comment-3513th-meeting-123rd-session-of-humanrights-committee $/ 5813062881001 /$ ?term $=>$.
55 ibid, Special Rapporteur Mr Shany, 2.02.10 min.
56 ibid, 2:03:12 min.

57 ibid, 20:04:54 min. 
The United Kingdom had suggested removing the words 'may eventually' from the first sentence of the paragraph, so that it would read 'States parties should take appropriate measures to address the general conditions in society that [may eventually] give rise to direct threats to life [...]'. The Special Rapporteur agreed that, due to the broad scope of the paragraph, the expression was not needed and supported its removal. ${ }^{58}$

The Rapporteur also drew attention to a proposal by the Expert mechanism on indigenous peoples that reference be made in the list of threatening conditions to 'land deprivation of indigenous peoples'. Whilst not disagreeing in principle, he was concerned both by the length of the paragraph and at its becoming overly specific - though he was content to defer to the Committee on this. ${ }^{59}$

Finally, attention was drawn to a proposal from Human Rights Watch and other organisations that reference be made to a further condition, namely 'climate change'.60 The Special Rapporteur noted, however, that reference was made to climate change in paragraph 65 (now 62) and, once again, drew attention to the length of the paragraph. ${ }^{61}$

In the general discussion, Mr De Frouville noted that the 'harmful consequences of climate change' constituted 'a very important issue that is becoming even more important for us' and therefore 'should have a place in the paragraph'. ${ }^{62}$ This general concern was echoed by Mr Politi, but he argued that: ${ }^{63}$

As regards the issue of climate change, I don't have obviously anything against including it, but perhaps the concern according to which we are discussing climate change could be accommodated by replacing the expression 'pollution of the environment' with 'environmental degradation' which would encompass phenomena like climate change. I repeat. I am not against specifically including climate change but I suspect there are also other causes for environmental degradation that are not strictly included in the notion of pollution of the environment. ${ }^{64}$

Pollution is indeed only one element of environmental degradation, which has a broader scope and links the text of the GC directly to the language used in the Rio Declaration on Environment and Development, which includes this formulation in several principles. ${ }^{65}$ The term 'pollution' was regarded as too narrow, since it excludes phenomena such as climate change, natural processes, slow onset events, extreme weather events or landslides. This approach paves the way for connections to be made between environmental change and the right to life in a broader range of cases. It also secured

58 ibid, 21:12:30 min.

61 ibid, 20:10:30 min.
63 ibid, Mr Politi, from 2:25:08 to 20:26:05 min.

59 ibid, 2:08:56 min $\quad 60$ ibid, 20:10:20 min.

65 Principles 7, 12, 14, 15, Rio Declaration on Environment and Development, 31 ILM 874 (1992). 
consistency with the terminology and list of possible harms included and adopted in paragraph 65 (now 62).

As a result, the term 'eventually' was removed from first sentence of the paragraph. ${ }^{66}$ As regards the second sentence of paragraph $26,{ }^{67}$ it was accepted that 'Mr Politi [had] made a very good comment that we change pollution with degradation. Then in the footnotes we can make a reference to paragraph 65 (now 62) where we deal more at length with the environmental issue and climate change.' ${ }^{68}$ To address the concerns of Committee Members Mr Santos Pais ${ }^{69}$ and Ms Ilze Brands Kehris regarding the deprivation of land of indigenous peoples, ${ }^{70}$ a reference was included, based on the preamble of the UN Declaration on the Rights of Indigenous Peoples, to the 'deprivation of land, territories, resources of indigenous people'. ${ }^{71}$

\section{GENERAL COMMENT NO. 36 IN THEORY AND PRACTICE}

The process analysed in the previous section resulted in one of the most innovative aspects of GC No. 36. Paragraphs 26 and 62 of the GC now provide a firm foundation for the relationship between the right to life and environmental protection. The paragraphs are complementary. Paragraph 26 sets out positive obligations of a 'special character' which deal 'with the conditions of the causes of the violation'. ${ }^{72}$ States must therefore adopt 'appropriate measures to address' conditions that may constitute a threat to the enjoyment of a life with dignity. The legal grounding for this is provided by the obligation 'to respect and to ensure' the rights set out in Article 2 of the ICCPR ${ }^{73}$ and by the very wording of Article 6 itself ('This right shall be protected by law'). These provisions mean that there is a legally binding positive obligation for States to provide protection 'by law' against action by private or other actors that threatens human life, and also from conditions that 'may give rise to direct threats' (para 26) to life.

Read together, paragraphs 26 and 62 recognise that environmental degradation both enables and-in the form of climate change, extreme weather events, desertification, and the like - can also itself be one of the most 'direct' 74 and 'most pressing and serious threats' ${ }^{75}$ to the ability to enjoy the right to life with dignity. For this reason, States must protect the enjoyment of the right to life through 'appropriate measures' ${ }^{96}$ and 'respect

66 ibid, 2:33:07 min.

68 ibid, 2:34:11 min.

70 ibid, Ms Brands Kehris, 2:32:07 min.

71 ibid, Mr Shany, 2:34:33 min. See Preamble, Declaration on the Rights of Indigenous Peoples, UNGA Resolution (2 October 2007) A/RES/61/295.

72 Discussion of the GC No. 36 (Cont'd), HRC, 3323rd meeting, 118th Session (n 45) Special Rapporteur Mr Yuval Shany, 1.23.41 min.

73 See also HRC, General Comment No 31, The nature of the general legal obligation imposed on States Parties to the Covenant (26 May 2004) CCPR/C/21/Rev.1/Add.13, in particular its para 8.

${ }^{74}$ GC No. 36 (n 5) para $26 . \quad 75$ ibid, para $62 . \quad 76$ ibid, para 26. 
and ensure the right to life' by implementing the obligation to 'preserve the environment and protect it against harm, pollution and climate change caused by public and private actors. ${ }^{77}$

As with the terminology used in environmental law, the reference to obligations to 'protect and preserve' expands the spatial scope of the obligation to prevent and therefore highlights the extraterritorial scope of the obligations arising from the right to life. ${ }^{78}$ This approach is consistent with the interpretation of the right to life given by the Inter-American Court in its 2017 Advisory Opinion on Human Rights and the Environment, which clarified the extraterritorial application of the American Convention in cases of environmental damage. ${ }^{79}$ The Inter-American Court concluded that 'the obligation to prevent environmental transboundary damage is an obligation recognised by international environmental law, by virtue of which States can be held responsible for significant damage caused to persons located outside their territory as a result of activities originating in their territory or under their authority or effective control'. ${ }^{80}$ Thus, by using the formula 'obligations to preserve the environment and protect it', when describing the relationship between the right to life and environmental degradation, the HRC is also highlighting the obligation to avoid transboundary environmental damage which might negatively affect the human rights of persons outside of their territorial jurisdiction resulting from activities undertaken within their territory or under their authority or effective control.

In light of the HRC's reasoning in Portillo Cáceres $v$ Paraguay and Teitiota $v$ New Zealand, the conceptual approach followed by the GC No. 36 can now be more concretely construed. In Portillo Cáceres v Paraguay, the Committee stated at the outset that the right to life cannot be properly understood if it is interpreted restrictively and that its protection requires States to adopt positive measures, as set out in paragraph 21 of the GC. ${ }^{81}$ The Committee also emphasised that the right to life refers to the right to enjoy a life 'with dignity' and not to be subject to actions or omissions that cause premature or unnatural death. ${ }^{82}$ It therefore reaffirmed the inherent interrelationship

77 ibid, para 62 (emphasis added); see also General Recommendation No. 25: Article 4, paragraph 1, Thirtieth session (2004), CEDAW, para 19; General Recommendation 23 (XXIII) on the rights of indigenous peoples, Fifty-First session (1997), CERD, para 4; General Comment No. 21 (2017) on children in street situations, CRC/C/GC/21 (21 June 2017) CRC, para 10 and 32 ['GC No. 21 CRC'].

78 See, for instance, arts 192 to 237 of the United Nations Convention on the Law of the Sea (UNCLOS), which are specifically devoted to the protection and preservation of the marine environment. This duty protects the environment as such, irrespective of its location. See In the matter of the South China Sea Arbitration before and Arbitral Tribunal constituted under Annex VII of the United Nations Convention on the Law of the Sea, PCA Case No. 2013-19, Award (12 July 2016) paras 927 and 941.

79 IACtHR Advisory Opinion on Human Rights and the Environment (n 4) paras 101-102.

80 ibid, para 103.

81 Portillo Cáceres v Paraguay (n 1) para 7.3; see also GC No. 6 (n 46) para 5.

82 ibid, para 7.3; GC No. 36 (n 5) para 3. 
between the right to life and human dignity. In particular, human dignity informs our understanding of the right to life and expands the scope of its protection to include situations, including of an environmental nature, that may put the right to life at risk. ${ }^{83}$ Most importantly, the Committee made it clear that States must take all appropriate measures to address the general conditions of society that may give rise to threats to the right to life or which prevent people from enjoying their right to life with dignity. The Committee noted that this may include 'pollution of the environment', ${ }^{84}$ and clarified that States parties may be violating Article 6 of the ICCPR even if this has not yet resulted in the loss of life. ${ }^{85}$

Similarly, in its interpretation in Teitiota $v$ New Zealand, the HRC made several important observations. First, it clarified that the right to life 'cannot be properly understood if it is interpreted in a restrictive manner, and that its protection requires States parties to adopt positive measures' ${ }^{86}$ Moreover, it relied on GC No. 36 for the proposition that the right to life also includes the right of individuals to enjoy a life with dignity and to be free from acts or omissions that would cause their unnatural or premature death. ${ }^{87}$ Referring to its decision in Portillo Cáceres, the Committee then noted that 'the obligation of States parties to respect and ensure the right to life extends to reasonably foreseeable threats and life-threatening situations that can result in loss of life'. ${ }^{88}$ States may therefore 'be in violation of article 6 even if such threats and situations do not result in the loss of life' ${ }^{89}$ Thus, the Committee confirmed the use of the 'foreseeability' standard in its ascertainment of real risk of irreparable harm to an individual's right to life, which had been inconsistently followed in previous HRC non-refoulement cases. ${ }^{90}$ Significantly, the Committee elaborated on paragraph 62 of the GC No. 36 affirming that 'environmental degradation, climate change and unsustainable development constitute some of the most pressing and serious threats to the ability of present and future generations to enjoy the right to life'. ${ }^{91}$ It also relied on paragraph 62 of the GC No. 36 in assessing whether there was clear arbitrariness, error or injustice in the evaluation by the New Zealand authorities of the applicant's complaint.

83 See also Marcia Cecilia Trujillo Calero v Ecuador (CESCR, 14 November 2018, Comm No. 10/2015, E/C.12/63/D/10/2015) para 22. Among General Comments, see GC No. 36 (n 5) paras 3, 26, 62; see also General Recommendation 21 (XXI) on the right to self-determination, CERD, Fortyeighth session (1996) para 5; General Comment No. 14 (2000), The right to the highest attainable standard of health (art 12 of the ICESCR), E/C.12/2000/4, 11 (11 August 2000) CESCR, para 1 and fn 13; GC No. 21 CRC (n 77) paras 29, 50.

${ }^{84}$ GC No. 36 (n 5) para 36 (emphasis added); see also Portillo Cáceres v Paraguay (n 1) para

7.4. $\quad{ }_{85}$ Portillo Cáceres v Paraguay (n 1) para $7 . \quad 86$ ibid, para 9.4.

${ }_{87}$ See GC No. 36, para 3; see also Portillo Cáceres v Paraguay (n 1) para 7.3.

88 See Toussaint v Canada (HRC, 24 July 2018, Comm No. 2348/2014) para 11.3; Portillo Cáceres v Paraguay (n 1) para 7.5.

${ }^{89}$ Portillo Cáceres v Paraguay (n 1) para 7.3.

90 See also, for instance, NS v Russian Federation (HRC, 1 June 2015, Comm No. 2192/2012) para 10.4; Hamida v Canada (HRC, 18 March 2010, Commn No. 1544/2007) para 8.7.

91 Teitiota $v$ New Zealand (n 7) para 9.4. 
The complaint also gave the HRC the opportunity to identify four scenarios that can cause a 'real risk of harm'. It first noted that a general situation of violence, such as that resulting from overcrowding or private land disputes in Kiribati, is only of sufficient intensity to create a real risk of irreparable harm under Articles 6 or 7 of the Covenant in the most extreme cases, where there is a real risk of harm simply by virtue of an individual being exposed to such violence on return, ${ }^{92}$ or where the individual in question is in a particularly vulnerable situation. ${ }^{93}$ The Committee acknowledged that 'sporadic' incidents of violence are not enough and that harm can also derive from 'non-state actors who engage in acts of violence during land disputes'. ${ }^{94}$ Secondly, it added that a risk can also be determined when 'the supply of fresh water is inaccessible, insufficient or unsafe so as to produce a reasonably foreseeable threat of a health risk that would impair his right to enjoy a life with dignity or cause his unnatural or premature death'. ${ }^{95}$ Thirdly, it noted and that 'the lack of alternatives to subsistence livelihoods may place individuals at a heightened risk of vulnerability to the adverse effects of climate change'. ${ }^{96}$ To establish this risk, the Committee must have information indicating that when the applicant's removal occurred, there was 'a real and reasonably foreseeable risk that he would be exposed to a situation of indigence, deprivation of food, and extreme precarity that could threaten his right to life, including his right to a life with dignity'. 97 Thus, in the last two scenarios, the HRC reaffirmed the 'foreseeability' standard, and it also recognised the complementarity between paragraph 26 of GC No. 36, which includes access to essential goods and services - eg food and water-within the conditions required by the right to life, and its paragraph 62, which lists climate change among the threats to the enjoyment of the right to life. The fourth scenario identified by the Committee concerned 'overpopulation and frequent and increasingly intense flooding and breaches of sea walls' ${ }^{98}$ In this context, it clarified that '[b]oth sudden-onset events (such as intense storms and flooding) and slow-onset processes (such as sea level rise, salinization, and land degradation) can propel cross-border movement of individuals seeking protection from climate change-related harm'. ${ }^{99}$ Importantly, it also noted 'that without robust national and international efforts, the effects of climate change in receiving states may expose individuals to a violation of their rights under articles 6 or 7 of the Covenant, thereby triggering the non-refoulement obligations of sending states'. ${ }^{100}$ Such would be the case if 'an entire country bec[ame] submerged'.${ }^{101}$

92 cf Sufi and Elmi v United Kingdom, ECtHR, App No. 8319/07 and 11449/07, Judgment of 28 June 2011, paras 218, 241.

93 Teitiota v New Zealand (n 7) para 9.7. See Jasin v Denmark (HRC, 25 September 2015 Comm No. 2360/2014) paras 8.8, 8.9; Warsame v Canada (HRC, 1 September 2011, Comm No. 1959/ 2010) para 8.3.

95 ibid, para 9.8 (emphases added).

95 ibid, para 9.8 (emphases added). 96 ibid, para 9.9 (emphasis added).

100 ibid.

94 Teitiota $v$ New Zealand (n 7), para 9.7.

bid, para 9.10 (emphasis added). 99 ibid, para 9.11 . 
Taken together, Portillo Cáceres and Teitiota illustrate the practical relevance of the two environmental paragraphs of GC No. 36. This is significant for the understanding of the Covenant but, also, more generally, for reflecting at the universal level approaches previously followed at the regional level.

\section{AN 'UNDENIABLE RELATIONSHIP': ENVIRONMENTAL PROTECTION AND THE RIGHT TO LIFE}

In its 2017 Advisory Opinion on Human Rights and the Environment, the Inter American Court of Human Rights (IACtHR) recognized 'the existence of an undeniable relationship between the protection of the environment and the realization of other human rights, in that environmental degradation and the adverse effects of climate change affect the effective enjoyment of human rights'. ${ }^{102}$ In Portillo Cáceres $v$ Paraguay, the HRC also described the relationship between environmental protection and the realisation of human rights as 'undeniable'. ${ }^{103}$ Moreover, the Committee expressly remarked on the 'developments in this area in other international instances', a reference to regional mechanisms, when concluding that the degradation of the environment caused by Paraguay had resulted in a violation of the right to life of the complainants. The connection between the regional and universal levels is therefore expressly made. This calls for two observations.

First, by adopting a progressive approach, the Committee has endorsed the approach found in the case law of regional courts concerning the interdependence between the protection of the environment and the right to life. The IACtHR has stated that the protection of the environment is a precondition for a decent life. ${ }^{104}$ The African Commission on Human and Peoples' Rights has considered, in a number of opinions, ${ }^{105}$ that the right to life 'envisages the protection not only of life in a narrow sense, but of

102 IACtHR Advisory Opinion on Human Rights and the Environment (n 4) para 47, 108; see also Preamble, Additional Protocol to the American Convention on Human Rights in the Area of Economic, Social and Cultural Rights, 16 November 1999.

103 Portillo Cáceres v Paraguay (n 1 para 7.4.

104 Advisory Opinion on Human Rights and the Environment (n 4) para 47, 108ff. See also Case of the Kaliña and Lokono Peoples v Suriname, Merits, reparations and costs. Judgment of 25 November 25 2015. Series C No. 309, para 172; Case of the Xákmok Kásek Indigenous Community v Paraguay, Merits, reparations and costs. Judgment August 24, 2010. Series C No. 214, para 187; Kawas Fernández v Honduras, IACtHR, Judgment of 3 April 2009, Serie C No. 196, para 148; Yakye Axa Indigenous Community v Paraguay, Merits, Reparations and Costs, Judgment of June 17, 2005. Series C No. 125, para 163.

105 See Ogoni (n 4) para 3 (emphasis added); Sudan Human Rights Organisation \& Centre on Housing Rights and Evictions (COHRE) v Sudan, (ACommHPR, 27 May 2009, Comm No. 279/03296/05) para 146; Centre for Minority Rights Development and Minority Rights Group International on behalf of Endorois Welfare Council $v$ Kenya, (ACommHPR, 25 November 2009, Comm No. 276/2003), para 216 ['Endorois Case']. 
dignified life, ${ }^{106}$ and has emphasised the right to life in dignity. ${ }^{107}$ Similarly, the European Court of Human Rights (ECtHR) has confirmed on many occasions that severe degradation of the environment may amount to a violation of the right to life. ${ }^{108}$ Some of these precedents were directly acknowledged by the HRC in Teitiota $v$ New Zealand. In the words of the Committee, its interpretation was indeed supported by regional human rights tribunals, which have clearly established that 'environmental degradation can compromise effective enjoyment of the right to life' and 'that severe environmental degradation can adversely affect an individual's well-being and lead to a violation of the right to life'. ${ }^{109}$

Secondly, the HRC's decisions in Portillo Cáceres v Paraguay and Teitiota $v$ New Zealand can be seen as an example of the more general concern for environmental degradation by UN treaty bodies and non-treaty mechanisms. For instance, the CESCR had already noted with concern that 'the expansion of soybean cultivation has resulted in the indiscriminate use of agro-toxins, causing deaths and diseases', and it had urged the relevant State party 'to take urgent measures to control that the cultivation of soybeans does not entail detriment in the enjoyment, by the population, of the rights recognised by the Covenant'. ${ }^{110}$

Placed in this broader context, Portillo Cáceres $v$ Paraguay and Teitiota $v$ New Zealand are not only landmark decisions for the HRC. They crystallise a deeper and wider body of jurisprudence and practice on the existence of an 'undeniable relationship' between environmental protection and the right to life in dignity. Together with GC No. 36, the decisions of the HRC, as a global body interpreting a global treaty, have potentially significant implications for future cases brought before the Committee ${ }^{111}$ or elsewhere.

\footnotetext{
106 General Comment No. 3 on the African Charter on Human and Peoples' Rights: The Right to Life (Article 4), ACommHPR, 4 to 18 November 2015, Introduction, para 3 ['GC No. 3 ACommHPR'].

${ }^{107}$ Principles and Guidelines on the Implementation of Economic, Social and Cultural Rights in the African Charter on Human and Peoples' Rights, ACommHPR (November 2010) para 78; GC No. 3 ACommHPR, Introduction, paras 3, 6, 11, 36, 43; Principles and Guidelines on Human and Peoples' Rights while Countering Terrorism in Africa, para E, Part 3 Liberty, Arrest, And Detention, ACommHPR, Fifty-Sixth Ordinary Session in Banjul, Gambia (April 21 to 7 May 2015).

${ }_{108}$ M. Özel and al. $v$ Turkey, ECtHR, App No. 46221/99, Judgment of 17 November 2015, paras 170, 171 and 200 ['Özel and al. $v$ Turkey']; Budayeva et al. v Russia, App No. 15339/02, 21166/02, 20058/02, 11673/02 and 15343/02, Judgment of 20 March 2008, paras 128-130, 133 and 159; Öneryildiz v Turkey, ECtHR, App No. 48939/99, 30 November 2004, paras 71, 89, 90 and 118.

${ }_{109}$ Teitiota $v$ New Zealand (n 7) para 9.5.

110 E/C.12/PRY/CO/3 (28 November 20070 para 16 and 27. See also CEDAW, CEDAW/C/ $\mathrm{PRY} / \mathrm{CO} / 6$ (8 November 2011) para 32 and 33; CRC, CRC/C/PRY/CO/3 (10 February 2010) para 51 and Special Rapporteur on extreme poverty and human rights, A/HRC/20/25/Add.2 (3 April 2012) para 47 and 48.

111 See, for instance, Torres Straits Islanders v Australia (n 8).
} 


\section{MAKING CONNECTIONS}

The link between environmental harm and the rights to life and to private and family life has long been established, especially by regional courts. Generally speaking, environmental protection and general human rights have been linked two main legal prisms, i.e. 'integrity' and 'cultural'. ${ }^{112}$

Before Portillo Cáceres and Teitiota, the HRC had mainly focused on the cultural connection, ${ }^{113}$ with the few cases relating to integrity faring less well. ${ }^{114}$ The HRC first adopted the right to life as a prism through which to assess the environmental dimension of the ICCPR in cases concerning the risks presented by nuclear tests or waste. ${ }^{115}$ However, those were considered inadmissible. In the early 1990s, the link between environmental protection and human rights found expression through a second prism, the right to the enjoyment of one's culture (Article 27 of the ICCPR). The Committee considered that the cultural ties between certain minority groups and their natural environment, represented by their lands and natural resources, deserved protection. ${ }^{116}$ In numerous cases such complaints were ultimately deemed inadmissible or rejected at the merits' stage. ${ }^{117}$ Yet, this body of practice helped clarify the two main legal prisms ${ }^{118}$ through which the connection between human rights and environmental protection had been approached at the universal and regional levels. The case law of the ECtHR followed mostly, although not solely, ${ }^{119}$ the first prism, ${ }^{120}$ whilst until the Advisory Opinion on Human Rights and the Environment, the ICommHR and the ICtHR had mainly relied on the second. ${ }^{121}$ The African Commission developed and referred to both, possibly because of the focus of its constitutive instrument, the African Charter, on both individual and peoples' rights. ${ }^{122}$

In Portillo Cáceres and Teitiota, the HRC has for the first time concretely elaborated on the link between the right to life and environmental protection

112 Dupuy and Viñuales (n 4) $368 . \quad 113$ See above (n 14). $\quad{ }^{114}$ See above (n 15).

115 See E.H.P. v Canada (n 2); see also Bordes et Temeharo v France (n 15).

116 See HRC, General Comment No. 23: Protection of Minorities (Art. 27), 4 August 1994, CCPR/C/21/Rev.1/Add.5, para 3.2; see also above (n 2).

117 See D Shelton, 'The Human Rights Committee's Decisions' Carnegie Council for Ethics in International Affairs (22 April 2005). $\quad{ }_{118}$ Dupuy and Viñuales (n 4) 368.

119 See, eg, T Koivurova, 'Jurisprudence of the European Court of Human Rights Regarding Indigenous Peoples: Retrospect and Prospects' (2011) 18 IJMGR 1; G Pentassuglia, 'Towards a Jurisprudential Articulation of Indigenous Land Rights' (2011) 22 EJIL 165; B Saul, Indigenous Peoples and Human Rights. International and Regional Jurisprudence (Hart Publishing 2016).

120 The entry point in the environmental case law of the Court has been predominantly, though not exclusively, the right to private and family life, ex Article 8 of the European Convention, see Lopez Ostra v Spain (n 4) para 51. The second prism, ie right to the enjoyment of one's culture, has, however, never made entrance in the Court's jurisprudence. See Dupuy and Viñuales (n 4) 370.

121 See Yanomani Indians v Brazil, ICommHR case 7615 (decision of 5 March 1985), subsequently confirmed most in Maya Indigenous Community of the Toledo District v Belize, ICommHR case 12.053 (report of 12 October 2004); see also Awas Tingni v Nicaragua (n 4) paras $145-55$.

${ }^{122}$ Ogoni (n 4) para 52; Endorois (n 105) paras 209, 250-251. 
as understood at the universal level. It has thereby built bridges not only between these two imperatives but also between the regional and the universal levels, and between theory (as expounded in GC No. 36) and actual practice. On the latter, the combination of paragraphs 26 and 62 of GC No. 36, as the drafters intended, has firmly established that environmental degradation constitutes a 'direct' and 'most pressing and serious threat' ${ }^{123}$ to the present and future enjoyment of the right to life 'with dignity'. For this reason, the preservation and protection of the environment constitute inherent conditions and components of the obligation to respect, protect and ensure the right to life, requiring States to adopt 'appropriate measures', ${ }^{124}$ against 'harm, pollution and climate change caused by both public and private actors'. ${ }^{125}$

Through their reliance on GC No. 36 as well as on the regional case law, Portillo Cáceres and Teitiota thus unveil the potential of the right to life as a means for expanding the environmental dimension not only of the ICCPR but also of other international instruments. 